\title{
IMPLEMENTASI KEPERAWATAN SEBAGAI WUJUD DARI PERENCANAAN KEPERAWATAN GUNA MENINGKATKAN STATUS KESEHATAN KLIEN
}

\author{
Rizka Safitri Siregar/181101041 \\ rizkasafitri223@gmail.com
}

\begin{abstract}
ABSTRAK
Keperawatan digunakan secara terus-menerus ketika merencanakan dan memberikan asuhan keperawatan dengan mempertimbangkan pasien sebagai figur central dalam merencanakan asuhan dengan mengobservasi respons pasien terhadap setiap tindakan sebagai penatalaksanaan dalam suatu asuhankeperawatan.Pada saat implementasi perawat harus melaksanakan hasil dari rencana keperawatan yang di lihat dari diagnosa keperawatan. Tujuan dari pelaksanaan adalah membantu klien dalam mencapai tujuan yang telah ditetapkan, yang mencakup peningkatan kesehatan, pencegahan, penyakit, pemulihan kesehatan dan memfasilitasi koping. Metode yang digunakan adalah metode kualitatif dimana maksudnya dengan cara mengumpulkan sebanyak-banyaknya data untuk dianalisis. Yaitu dengan Literature review ini dengan menganalisis yang berfokus pada pentingnya implementasi keperawatan dalam mengoptimalkan asuhan keperawatan. implemetasi keperawatan adalah kategori serangkaian perilaku perawat yang berkoordinasi dengan pasien, keluarga, dan anggota tim kesehatan lain untuk membantu masalah kesehatan pasien yang sesuai dengan perencanaan dan kriteria hasil yang telah ditentukan dengan cara mengawasi dan mencatat respon pasien terhadap tindakan keperawatan yang telah dilakukan.
\end{abstract}

Kata kunci : Status kesehatan, Implementasi keperawatan, Kesehatan pasien.

\section{PENDAHULUAN}

Implementasi keperawatan adalah serangkaian kegiatan yang dilakukan oleh perawat untuk membantu klien dari masalah status kesehatan yang dihadapi kestatuskesehatan yang baik yang menggambarkan kriteria hasil yang diharapkan. Ukuran intervensi keperawatan yang diberikan kepada klien terkait dengan dukungan dan pengobatan dan tindakan untuk memperbaiki kondisi dan pendidikan untuk klienkeluarga atau tindakan untuk mencegah masalah kesehatan yang muncul dikemudian hari. Proses pelaksanaan implementasi harus berpusat kepada kebutuhan klien dan faktor-faktor lain yang mempengaruhi kebutuhan keperawatan\& strategi implementasikeperawatan\& dan 
kegiatan komunikasi. Implementasi keperawatan adalah kegiatan mengkoordinasikan aktivitas pasien, keluarga, dan anggota tim kesehatan lain untuk mengawasi dan mencatat respon pasien terhadap tindakan keperawatan yang telah dilakukan (Nettina, 2002). Jadi, implemetasi keperawatan adalah kategori serangkaian perilaku perawat yang berkoordinasi dengan pasien, keluarga, dan anggota tim kesehatan lain untuk membantu masalah kesehatan pasien yang sesuai dengan perencanaan dan kriteria hasil yang telah ditentukan dengan cara mengawasi dan mencatat respon pasien terhadap tindakan keperawatan yang telah dilakukan.

\section{TUJUAN}

Tujuan dari pelaksanaan/implementasi adalah membantu klien dalam mencapai tujuan yang telah ditetapkan, yang mencakup peningkatan kesehatan, pencegahan, penyakit, pemulihan kesehatan dan memfasilitasi koping. Melaksanakan hasil dari rencana keperawatan untuk selanjutnya di evaluasi untukmengetahui kondisi kesehatan pasien dalam periode yang singkat, untuk mempertahankan daya tahan tubuh, untuk mencegah komplikasi, untuk menemukan perubahan system tubuh, untuk memberikan lingkungan yang nyaman bagi klien, dan untuk mengimplementasi pesan dokter.

\section{METODE}

Metode yang digunakan adalah metode kualitatif dimana maksudnya dengan cara mengumpulkan sebanyak-banyaknya data untuk dianalisis. Yaitu dengan Literature review ini dengan menganalisis yang berfokus pada pentingnya implementasi keperawatan dalam mengoptimalkan asuhan keperawatan. Adapun tinjauan literatur yang digunakan seperti buku teks, buku referensi, jurnal, dan google scholar. Dengan kata kunci Pentingnya Implementasi, Asuhan Keperawatan, Implementasi keperawatan. Dan literature yang digunakan adalah 14 literatur yang diterbitkan 10 tahun terakhir. 


\section{HASIL/PEMBAHASAN}

Proses keperawatan adalah metode dimana suatu konsep diterapkan dalam praktik keperawatan. Hal ini bisa disebut sebagai suatu pendekatan problem-solving yang memerlukan ilmu, teknik, dan ketrampilan interpersonal dan ditujukan untuk memenuhi kebutuhan klien/ keluarga. Proses keperawatan terdiri dari lima tahap yang sequensial dan berhubungan. Antara lain yaitu pengkajian, diagnosis, perencanaan, pelaksanaan, dan evaluasi. Tahap tersebut berintegrasi dalam mendefinisikan suatu tindakan perawatan. Salah satunya adalah implementasi atau pelaksanaan. Proses keperawatan menyediakan struktur bagian praktis dengan penggunaan pengetahuan dan keterampilan yang dilakukan

oleh perawat untuk mengekspresikankebutuhan perawatan (human caring). Keperawatan digunakan secara terus-menerus ketika merencanakan dan memberikan asuhan keperawatan dengan mempertimbangkan pasien sebagai figur central dalam merencanakan asuhan dengan mengobservasi respons pasien terhadap setiap tindakan sebagai penatalaksanaan dalam suatu asuhankeperawatan.Pada saat implementasi perawat harus melaksanakan hasil dari rencana keperawatan yang di lihat dari diagnosa keperawatan. Pada saat implementasi perawat harus melaksanakan hasil dari rencana keperawatan yang di lihat dari diagnosa keperawatan. Di mana perawat membantu klien dari masalah status kesehatan yang dihadapi kestatus kesehatan yang lebih baik yang menggambarkan kriteria hasil yang diharapkan. Implementasi keperawatan adalah serangkaian kegiatan yang dilakukan oleh perawat untuk membantu klien dari masalah status kesehatan yang dihadapi kestatus kesehatan yang lebih baik yang menggambarkan kriteria hasil yang diharapkan. Implementasi merupakan inisiatif dari rencana tindakan untuk mencapai tujuan yang spesifik. Tahap pelaksanaan dimulai setelah rencana tindakan disusun dan ditujukan pada nursing orders untuk membantu klien mencapai tujuan yang diharapkan. Oleh karena itu rencana tindakan yang spesifik dilaksanakan untuk memodifikasi faktor-faktor yang mempengaruhi masalah kesehatan klien. Tipe implementasi keperawatan Secara garis besar terdapat tiga kategori dari implementasi keperawatan (Craven dan Hirnle, 2000) antara lain:

a. Cognitive implementations yaitu Meliputi pengajaran atau pendidikan, menghubungkan tingkat pengetahuan klien dengan kegiatan hidup sehari-hari, membuat strategi untuk klien 
dengan disfungsi komunikasi, memberikan umpan balik, mengawasi tim keperawatan, mengawasi penampilan klien dan keluarga, serta menciptakan lingkungan sesuai kebutuhan, dan lain lain.

b. Interpersonal implementations yaitu Meliputi koordinasi kegiatan-kegiatan, meningkatkan pelayanan, menciptakan komunikasi terapeutik, menetapkan jadwal personal, pengungkapan perasaan, memberikan dukungan spiritual, bertindak sebagai advokasi klien, role model, dan lain lain.

c. Technical implementations yaitu Meliputi pemberian perawatan kebersihan kulit, melakukan aktivitas rutin keperawatan, menemukan perubahan dari data dasar klien, mengorganisir respon klien yang abnormal, melakukan tindakan keperawatan mandiri, kolaborasi, dan rujukan, dan lain-lain.

Dalam pelaksanaannya terdapat tiga jenis implementasi keperawatan, antara lain:

a. Independent implementations adalah implementasi yang diprakarsai sendiri oleh perawat untuk membantu klien dalam mengatasi masalahnya sesuai dengan kebutuhan, misalnya: membantu dalam memenuhi activity daily living (ADL), memberikan perawatan diri, mengatur posisi tidur, menciptakan lingkungan yang terapeutik, memberikan dorongan motivasi, pemenuhan kebutuhan psiko-sosio-spiritual, perawatan alat invasive yang dipergunakan klien, melakukan dokumentasi, dan lain-lain.

b. Interdependen/ Collaborative implementations adalah tindakan keperawatan atas dasar kerjasama sesama tim keperawatan atau dengan tim kesehatan lainnya, seperti dokter. Contohnya dalam hal pemberian obat oral, obat injeksi, infus, kateter urin, naso gastric tube (NGT), dan lain-lain. Keterkaitan dalam tindakan kerjasama ini misalnya dalam pemberian obat injeksi, jenis obat, dosis, dan efek samping merupakan tanggungjawab dokter tetapi benar obat, ketepatan jadwal pemberian, ketepatan cara pemberian, ketepatan dosis pemberian, dan ketepatan klien, serta respon klien setelah pemberian merupakan tanggung jawab dan menjadi perhatian perawat.

c. Dependent implementations adalah tindakan keperawatan atas dasar rujukan dari profesi lain, seperti ahli gizi, physiotherapies, psikolog dan sebagainya, misalnya dalam hal: 
pemberian nutrisi pada klien sesuai dengan diit yang telah dibuat oleh ahli gizi, latihan fisik (mobilisasi fisik) sesuai dengan anjuran dari bagian fisioterapi.

Ada tiga prinsip pedoman implementasi keperawatan (Haryanto,2007), yaitu :

a. Mempertahankan keamanan klien dengan Keamanan merupakan focus utama dalam melakukan tindakan. Oleh karena, tindakan yang membahayakan tidak hanya dianggap sebagai pelanggaran etika standar keperawatan professional, tetapi juga merupakan suatu tindakan pelanggaran hukum yang dapat ditutut.

b. Memberikan asuhan yang efektif dengan memberikan asuhan yang efektif adalah memberiakan asuhan sesuai dengan yang harus dilakukan semakin baik pengetahuan dan pengalaman seorang perawat, maka semakin efektif asuhan yang diberikan.

c. Memberikan asuhan seefisien mungkin dengan memberikan asuhan yang efisien berarti perawat dalam memberikan asuhan dapat mengunakan waktu sebaik mungkin sehingga dapat menyelesaikan masalah kilen.

\section{Tahap - Tahap Implementasi}

a. Tahap I: Persiapan merupakan tahap awal tindakan keperawatan ini menuntut perawat mempersiapkan segala sesuatu yang diperlukan dalam tindakan. Meliputi : Review tindakan keperawatan yang diidentifikasi pada tahap perencanaan, menganalisa pengetahuan dan ketrampilan keperawatan yang diperlukan, mengetahui komplikasi dari tindakan keperawatan yang mungkin timbul, menentukan dan mempersiapkan peralatan yang diperlukan, mempersiapkan lingkungan yang kondusif sesuai dengan tindakan, dan mengidentifikasi aspek hukum dan etik terhadap resiko dari potensi tindakan.

b. Tahap II: Intervensi merupakan tahap yang berfokus pada pelaksanaan tindakan perawatan adalah kegiatan pelaksanaan tindakan dari perencanaan untuk memenuhi kebutuhan fisik dan emosional. Pendekatan ini meliputi: Independen adalah suatu kegiatan yang dilaksanakan oleh perawat tanpa petunjuk dan perintah dari dokter atau tenaga kesehatan lainnya. Tipe tindakan independen keperawatan dapat dikatagorikan menjadi 4 , yaitu tindakan diagnostik, tindakan terapeutik, tindakan edukatif, dan tindakan merujuk, interdependen menjelaskan suatu kegiatan yang memelukan suatu kerjasama dengan tenaga 
kesehatan lainnya,misalnya tenaga sosial, ahli gizi, fisioterapi dan dokter, dan dependen ini berhubungan dengan pelaksanaan rencana tindakan medis. Tindakan tersebut menandakan suatu cara dimana tindakan medis dilaksanakan.

c. Tahap III: Dokumentasi merupakan pelaksanaan tindakan keperawatan harus diikuti oleh pencatatan yang lengkap dan akurat terhadap suatu kejadian dalam proses keperawatan. Ada 3 tipe sistem pencatatan yang digunakan pada dokumentasi : Sources-Oriented records, Problem-Oriented records, dan Computer-Assissted records

Menurut Wilkinson (2007) implementasi yang bisa dilakukan oleh perawat terdiri dari:

a. Do (melakukan), implementasi pelaksanaan kegiatan dibagi dalam beberapa kriteria yaitu: Dependen Interventions: dilaksanakan dengan mengikuti order dari pemberi perawatan kesehatan lain, Collaborative (interdependen): interpensi yang dilaksanakan dengan professional kesehatan lainnya, dan Independent (autonomous) Intervention: intervensi dilakukan dengan melakukan nursing orders dan sering juga digabungkan dengan order dari medis

b. Delegate (mendelegasikan): pelaksanaan order bisa didelegasikan hanya saja ada beberapa tanggung jawab yang perlu dicermati oleh pemberi delegasi yaitu apakah tugas tersebut tepat untuk didelegasikan, apakah komunikasi tepat dilakukan, dan apakah ada supervise atau pengecekan aktivitas yang didelegasikan.

c. Record (mencatat), pencatatan bisa dilakukan dengan berbagai format tergantung pilihan dari setiap institusi.

Metode Implementasi antara lain : (1) membantu dalam Aktivitas Kehidupan Sehari-Hari merupakan aktivitas Kehidupan Sehari-Hari (AKS) adalah aktivitas yang biasanya dilakukan sepanjang hari/normal, aktivitas tersebut menyangkut : ambulasi, makan, berpakaian, mandi, menyikat gigi, dan berhias. Kondisi yang mengakibatka kebutuhan AKS dapat bersifat akut, kronis, temporer, dan permanen. Sebagai contoh, klien pascaopratif yang tidak mampu secara mandiri menyelesaikan semua AKS, sementara terus beralih melewati periode pascaopratif, klien secara bertahap kurang bergantung pada perawat untuk menyelesaikan AKS. 
(2) Konseling merupakan metoda implementasi yang membantu klien menggunakan proses pemecahan masalah untuk mengenali dan menangani stres dan yang memudahkan hubungan interpersonal diantara klien, keluarga dan tim perawat kesehatan. Klien dengan diagnosa psikiatris membutuhkan terapi oleh perawat yang mempunyai keahlian dalam keperaatan psikiatris oleh pekerja social, psikiater dan psikolog.

(3) Penyuluhan Digunakan menyajikan prinsip, prosedur dan teknik yang tepat tentang perawatan kesehatan untuk klien dan untuk menginformasikan klien tentang status kesehatanya.

(4) Memberikan Asuhan Keperawatan Langsung untuk mencapai tujuan terapeutik klien, perawat melakukan intervensi untuk mengurangi reaksi yang merugikan dengan menggunakan tindakan pencegahan dan preventive dalam memberikan asuhan.

\section{KESIMPULAN}

Implemetasi keperawatan adalah kategori serangkaian perilaku perawat yang berkoordinasi dengan pasien, keluarga, dan anggota tim kesehatan lain untuk membantu masalah kesehatan pasien yang sesuai dengan perencanaan dan kriteria hasil yang telah ditentukan dengan cara mengawasi dan mencatat respon pasien terhadap tindakan keperawatan yang telah dilakukan. implementasi pelaksanaan kegiatan dibagi dalam beberapa kriteria yaitu: Dependen Interventions: dilaksanakan dengan mengikuti order dari pemberi perawatan kesehatan lain, Collaborative (interdependen): interpensi yang dilaksanakan dengan professional kesehatan lainnya, dan Independent (autonomous) Intervention: intervensi dilakukan dengan melakukan nursing orders dan sering juga digabungkan dengan order dari medis.

\section{REFERENSI}

Bausat, N. (2016). Strategi RSUD Tenriawaru Kabupaten Bone menuju implementasi sistem pembayaran prospektif. Jurnal Administrasi Rumah Sakit Indonesia, 1(2).

Efendi, N. F. (2015). Pendidikan dalam keperawatan. Surabaya: Salemba Medika 
Fisher, A. (2009). Berfikir Kritis: Sebuah Pengantar. Jakarta: Erlangga

Khamida, K., \& Mastiah, M. (2015). Kinerja Perawat Dalam Memberikan Asuhan Keperawatan Berpengaruh Terhadap Kepuasan Pasien Rawat Inap. Journal of Health Sciences, 8(2).

Potter, A.P., \& Perry, G.A. (2010). Fundamental Keperawatan Buku 1 Edisi 7. Jakarta : Salemba Medika

Potter, A., \& Perry, A. (2017). Buku Ajar Fundamental Keperawatan: Konsep, Proses, dan Praktik (4th ed.). Jakarta: Buku Kedokteran EGC.

Rosdahl, C. B., \& Kowalski, M. T. (2014). Buku Ajar Keperawatan Dasar. Jakarta: EGC

Sari, I. P. (2016). Hubungan Pengetahuan Perawat Tentang Model Asuhan Keperawatan Metode Tim Dengan Implementasinya Di Ruang Bedah Flamboyan Rsud Dr Soetomo Surabaya. Medica Majapahit, 8(2), 74-79.

Serri, H. (2010). Konsep dan Dokumentasi Proses Keperawatan. Jakarta: Trans Info Medika

Simamora, R. H. (2008). Peran Manajer Dalam Pembinaan Etika Perawat Pelaksana Dalam Peningkatan Kualitas Pelayanan Asuhan Keperawatan. IKESMA, 4(2)

Simamora, R. (2009). Dokumentasi Proses Keperawatan.

Simamora, R. (2010). Komunikasi dalam keperawatan

Sumijatun. (2010). Konsep Dasar Menuju Keperawatan Profesional. Jakarta: Trans Info Medika

Syafrini, R. O., Keliat, B. A., \& Putri, Y. S. E. (2015). Efektivitas Implementasi Asuhan Keperawatan Isolasi Sosial Dalam Mpkp Jiwa Terhadap Kemampuan Klien. Jurnal Ners, 10(1), 175-182. 
Tarwoto, \& Wartonah. (2010). Kebutuhan Dasar Manusia dan Proses Keperawatan. Jakarta: Salemba Medika 